\title{
Particle size distribution and outflow rate from the rumen of cows fed rations with different protein sources*
}

\author{
J.J. Pająk, Teresa Żebrowska, Zofia Długołęcka \\ and M. Korczyński
}

The Kielanowski Institute of Animal Physiology and Nutrition, Polish Academy of Sciences

05-100 Jablonna, Poland

(Received 31 January 1997; accepted 24 October 1997)

\begin{abstract}
Three non-lactating cows of about $470 \mathrm{~kg} \mathrm{BW}$ were fed rations of meadow hay and concentrate (79:21) containing fish meal (ration F) or rapeseed oilmeal (ration R).

Total rumen content was evacuated manually before feeding $(0 \mathrm{~h})$ and 4 and $8 \mathrm{~h}$ after feeding. The interval between two successive evacuations was 7 days. Rate of passage of solid particles from the rumen was measured using $\mathrm{Cr}$ mordanted hay, liquid fraction outflow using $\mathrm{Co}$-EDTA as indicators. Particle size distribution in the digesta was determined by wet-sieving using screen mesh sizes $5.0 ; 1.0$ and $0.25 \mathrm{~mm}$.

The total amounts of rumen digesta, dry matter and crude protein measured at different times after feeding did not depend on the source of protein in the ration. The potential digestibility of crude fibre, ADF, NDF and ADL was higher $(\mathrm{P}<0.05)$ on the ration with fish meal, particularly 8 and $12 \mathrm{~h}$ after feeding. The proportion of the different sizes of particles in DM of total digesta was uniform over time after feeding. The proportion of particles smaller than $1 \mathrm{~mm}$ was only a little higher in the rumen of cows fed ration $F(P<0.05)$. Crude protein content was higher $(P<0.05)$ in particles larger than $5 \mathrm{~mm}$ and of lignin in particles smaller than $1 \mathrm{~mm}$ when feeding the fish meal-containing ration. The proportion of particles in the rumen DM smaller than $1 \mathrm{~mm}$ was $64 \%$ at 4 and $8 \mathrm{~h}$ and increased to about $70 \%$ at $12 \mathrm{~h}$ after feeding both rations.

The critical particle size was found to be $0.52 \mathrm{~mm}$, rumen outflow rate of the solid fraction was $6.6 \%$ and liquid fraction $15.5 \% / \mathrm{h}$; these parameters were not affected by the protein source in the diet.
\end{abstract}

KEY WORDS: rumen, protein, particle size, chemical composition, outflow rate

\footnotetext{
* Supported by the State Committee for Scientific Research, Grant No 5 S305021 05
} 


\section{INTRODUCTION}

Feed intake by ruminants depends to a considerable degree on the outflow rate of rumen digesta particles to the omasum and reticulum. The outflow of feed particles depends on their size. It is accepted that feed particles larger than $1 \mathrm{~mm}$ can not exit the rumen until they are reduced in size (Poppi et al., 1980, 1985). On the basis of particle size, the rumen content is divided into a pool of small particles $(<1.0 \mathrm{~mm})$ that exit the rumen, and large particles $(>1 \mathrm{~mm})$ that must be broken down before they can leave. The studies of Poppi et al. (1985) have shown that the size of the particles leaving the rumen does not undergo any major changes after passing through the remaining parts of the digestive tract. This suggests that the size of particles leaving the rumen can be determined on the basis of their size in the faeces.

Particle size and their proportion in the rumen digesta change with time after feeding and depend on feed mastication during its uptake and rumination (Ulyatt et al., 1986). Recently, the important role of bacteria in decreasing particle size was demonstrated using the in sacco method (Bowman and Firkins, 1996). Microorganisms do not reduce particle size directly, but by destroying the physical structure of plant tissues, facilitate reduction during rumination.

Numerous factors such as feed type, fibre content, and intake, may affect the rate at which feed particles are degraded in the rumen and their outflow rate. There is no information in the literature on the effect of nitrogen source on the above processes, although it is known that it can affect the digestion rate of organic substances and fibre in the rumen (McAllan and Smith, 1983; McAllan and Griffith, 1987; Dakowski, 1992).

The objective of this study was to determine the effect of protein source on changes in rumen particle size, chemical composition and the qualitative and quantitative chemical composition of the rumen contents at various times after feeding.

\section{MATERIAL AND METHODS}

\section{Animals and feeds}

The experiment was carried out on three non-lactating Black-and-White Lowland cows fitted with permanent Diamond rumen fistulae. The animals received rations (Table 1) composed of cut meadow hay, barley meal supplemented with a mineral mixture and rapeseed oilmeal $(R)$ in the first part of the experiment, and fish meal $(\mathrm{F})$ in the second. The feed was given in two rations at 8.00 and $20.00 \mathrm{~h}$ with free access to water. 
TABLE 1 Composition of the diets and a proportion of dry matter (DM), crude protein and crude fibre from the particular feed in the diet

\begin{tabular}{lcrrr}
\hline & & \multicolumn{3}{c}{ Proportion in the diet, \% } \\
\cline { 3 - 5 } Feed & $\mathrm{kg}$ & $\mathrm{DM}$ & crude protein crude fibre \\
\hline Diet $\mathrm{R}$ & & & & \\
$\quad$ ground barley & 1.0 & 9.9 & 9.4 & 1.9 \\
$\quad$ rapesced meal & 1.1 & 11.3 & 31.0 & 5.7 \\
meadow hay & 8.0 & 78.8 & 59.6 & 92.4 \\
Diet F & & & & \\
$\quad$ ground barley & 1.4 & 13.8 & 12.6 & 2.8 \\
$\quad$ fish meal & 0.7 & 7.4 & 30.4 & 0.0 \\
$\quad$ meadow hay & 8.0 & 78.8 & 57.0 & 97.2 \\
\hline
\end{tabular}

\section{Experimental design}

Rumen content sampling was begun after 21 days of feeding the experimental diet. The entire content was remeved from the rumen before feeding $(0)$, and 4 and $8 \mathrm{~h}$ after feeding. The contents were weighed, mixed manually, and $9 \mathrm{~kg}$ samples were taken, after which the remainder was quickly replaced in the rumen. An effort was made to keep the duration of the entire procedure under 45 min. The next emptying of the rumen of the same cow was carried out no earlier than after 7 days. The rumen content samples were divided into $500 \mathrm{~g}$ aliquots and frozen at $-18^{\circ} \mathrm{C}$.

The rumen content particles were separated into 3 fractions according to size (A: above $5 \mathrm{~mm}$; B: 1 to $5 \mathrm{~mm}, \mathrm{C}: 0.25$ to $1 \mathrm{~mm}$ ) by wet sieving using a Fritsch Analysette $3(20 \mathrm{~cm} \varnothing)$ sieves. A vibration amplitude of 7 , and 5 min duration of sieving with a water flow rate of $1.4 \mathrm{l} / \mathrm{min}$ were used, then the fraction was rinsed three times allowing free water fall (approx. 71 portions each time), then sieving was repeated for $5 \mathrm{~min}$ under running water $(1.41 / \mathrm{min})$. The share of fraction D (under $0.25 \mathrm{~mm}$ ) flowing out with the water in the separator was calculated.

The rate of passage of the solid fraction from the rumen was determined using $\mathrm{Cr}$ mordanted hay prepared according to Udén et al. (1980). Mordant was given in a single does of $120 \mathrm{~g} / \mathrm{cow}(7.2 \mathrm{~g} \mathrm{Cr})$ into the rumen before the morning feeding. The total faeces collection was conducted for $168 \mathrm{~h}$, taking samples every $4 \mathrm{~h}$ for the first 2 days, every $6 \mathrm{~h}$ for three days, every $8 \mathrm{~h}$ for the next two days, and every $12 \mathrm{~h}$ in the last two days.

The outflow of the liquid fraction from the rumen was determined using Co-EDTA (Udén et al., 1980). A solution of $300 \mathrm{ml}$ Co-EDTA containing $2.5 \mathrm{~g}$ Co was instilled into the rumen before the morning feeding. Samples of rumen fluid were taken after $2,4,6,8,12,16$ and $24 \mathrm{~h}$ to determine Co content. 
The content of the indigestible fraction in the rumen was determined after incubation of freeze-dried rumen contents $(4 \mathrm{~g}$ ) in nylon bags (pore size $42 \mathrm{~mm}$, external dimensions $11 \times 8 \mathrm{~cm}$ ) in the rumen for $288 \mathrm{~h}$. The content of potentially digestible rumen digesta components was calculated from the difference in the components of the freeze-dried sample of rumen contents and its indigestible fraction. The term ,potentially" was used since the real rumen digestibility is lower than determined in the above way because small particles may exit the rumen before $288 \mathrm{~h}$.

\section{Analytical methods}

Samples of rumen contents and its fractions were freeze-dried (Leybold GT3). These samples were used to determine dry matter, total $\mathrm{N}$ and crude fibre, NDF, ADF and ADL according to Van Soest (1973) using a Fibretec M apparatus.

The $\mathrm{Cr}$ and $\mathrm{Co}$ contents in faeces and in the rumen liquor were determined using a mass absorption spectrophotometer (Philips PU 9100X) in an acetylene flame and wave length of $357.9 \mathrm{~nm}(\mathrm{Cr})$ and $240.7 \mathrm{~nm}(\mathrm{Co})$ after previous mineralization of the samples.

The critical size of the particles was determined by wet sieving of $100 \mathrm{~g}$ of average daily faeces samples on a stack of $2.5 ; 2.0 ; 1.6 ; 1.0 ; 0.8 ; 0.25$ i $0.1 \mathrm{~mm}$ sieves using the same procedure as for separation of rumen digesta particles. The $\mathrm{pH}$ of fresh rumen contents was determined potentiometrically using an $\Phi 72$ Beckman pH-meter.

\section{Statistical analysis}

The data were subjected to two-factor variance analysis using STATGRAPHIC Plus 7.0 software.

\section{RESULTS}

Crude protein in rapeseed oilmeal and fish meal constituted about $30 \%$ of the crude protein content in the ration (Table 1). The proportion of meadow hay dry matter to the dry matter of concentrates was $79: 21$ in both rations.

Ration $\mathrm{R}$ contained slightly less crude protein and ether extract and somewhat more crude fibre and NDF, ADF and ADL than ration F (Table 2).

The largest amount of rumen digesta was found $4 \mathrm{~h}$ after feeding, on average 85 and $88 \mathrm{~kg}$ respectively for rations $\mathrm{R}$ and $\mathrm{F}$ (Table 3 ), ranging in individual cows from 81 to $95 \mathrm{~kg}$. The least was found before feeding, on average 68 and $77 \mathrm{~kg}$ for rations $\mathrm{R}$ and $\mathrm{F}$, respectively, while its mass in individual cows at this 
TABLE 2

Chemical composition of feeds (\%) and daily intake of nutrients $(\mathrm{kg})$

\begin{tabular}{lccccccc}
\hline Feed & DM & $\begin{array}{c}\text { Crude } \\
\text { protein }\end{array}$ & $\begin{array}{c}\text { Ether } \\
\text { extract }\end{array}$ & $\begin{array}{c}\text { Crude } \\
\text { fibre }\end{array}$ & NDF & ADF & ADL \\
\hline Ground barley & 87.8 & 11.2 & 2.0 & 4.9 & 28.0 & 7.5 & 3.7 \\
Rapeseed meal & 91.5 & 33.7 & 4.4 & 13.7 & 26.0 & 24.3 & 14.9 \\
Fish meal & 94.3 & 54.2 & 14.2 & - & - & - & - \\
Meadow hay & 87.8 & 8.9 & 2.1 & 30.3 & 60.8 & 39.9 & 9.8 \\
Daily intake, kg & & & & & & & \\
$\quad$ diet R & 8.91 & 1.20 & 0.24 & 2.62 & 5.43 & 3.53 & 0.99 \\
$\quad$ diet $F$ & 8.91 & 1.25 & 0.30 & 2.49 & 5.26 & 3.29 & 0.84 \\
\hline
\end{tabular}

time ranged between 64 and $81 \mathrm{~kg}$. The dry matter content of rumen digesta ranged from 97 to 134 and from 99 to $126 \mathrm{~g} / \mathrm{kg}$ contents, respectively. The protein source did not have a significant effect on the amount of digesta and its dry matter content. It was found, however, that the $\mathrm{pH}$ of the rumen content of cows receiving fish meal was higher $(\mathrm{P}<0.05)$ than those fed the ration containing rapeseed oilmeal. The time after feeding also did not have a significant effect on the value of the determinations (Table 3), it was found, however, that $4 \mathrm{~h}$ after feeding there was more DM in the whole rumen contents than before feeding $(\mathbf{P}<0.01)$.

TABLE 3

Amount of rumen digesta $(\mathrm{kg}), \mathrm{pH}$ and dry matter content, in different time after feeding

\begin{tabular}{cccccc}
\hline \multirow{2}{*}{ Diet } & $\begin{array}{c}\text { Time } \\
\mathrm{h}\end{array}$ & $\begin{array}{c}\text { Digesta } \\
\mathrm{kg}\end{array}$ & $\mathrm{pH}$ & \multicolumn{2}{c}{ Dry matter } \\
\cline { 5 - 6 } & 0 & 68.2 & $7.2^{\mathrm{a}}$ & 104 & $\mathrm{~kg}$ \\
\hline $\mathrm{R}$ & 4 & 85.3 & $7.1^{\mathrm{a}}$ & 121 & $7.1^{\mathrm{A}}$ \\
& 8 & 82.7 & $7.0^{\mathrm{a}}$ & 110 & $9.3^{\mathrm{B}}$ \\
& 0 & 76.6 & $7.4^{\mathrm{b}}$ & 116 & $8.9^{\mathrm{A}}$ \\
& & 87.9 & $7.2^{\mathrm{ab}}$ & 118 & $10.3^{\mathrm{B}}$ \\
& 8 & 85.1 & $7.3^{\mathrm{b}}$ & 106 & $9.0^{\mathrm{AB}}$ \\
\hline
\end{tabular}

$\mathrm{a}, \mathrm{b}-\mathrm{P}<0.05, \mathrm{~A}, \mathrm{~B}-\mathrm{P}<0.01$

When the fish meal-containing ration was fed, the crude protein content of the rumen (Table 4) was higher $(\mathrm{P}<0.05)$, while the ADL content lower $(\mathrm{P}<0.01)$ than when ration $\mathrm{R}$ was given. The percentage of $\mathrm{ADL}$ in rumen content $\mathrm{DM}$ $4 \mathrm{~h}$ after feeding was lower than in other periods $(\mathrm{P}<0.05)$. The ADL content in the DM of the rumen digesta before and $8 \mathrm{~h}$ after feeding did not differ 
TABLE 4

Chemical composition of rumen digesta, as per cent of DM, in different time after feeding

\begin{tabular}{ccccccc}
\hline Diet & $\begin{array}{c}\text { Time } \\
\mathrm{h}\end{array}$ & $\begin{array}{c}\text { Crude } \\
\text { protein }\end{array}$ & $\begin{array}{c}\text { Crude } \\
\text { fibre }\end{array}$ & NDF & ADF & ADL \\
\hline \multirow{3}{*}{$\mathrm{R}$} & 0 & $14.3^{\mathrm{a}}$ & 28.1 & 62.3 & 37.9 & $13.4^{\mathrm{Ab}}$ \\
& 4 & $14.2^{\mathrm{a}}$ & 29.9 & 60.4 & 39.0 & $11.3^{\mathrm{Aa}}$ \\
& 8 & $14.3^{\mathrm{a}}$ & 29.1 & 61.7 & 40.0 & $12.3^{\mathrm{Ab}}$ \\
& 0 & $16.1^{\mathrm{b}}$ & 29.0 & 62.4 & 41.4 & $9.8^{\mathrm{Bc}}$ \\
& 4 & $15.4^{\mathrm{b}}$ & 27.2 & 60.0 & 34.2 & $8.6^{\mathrm{Ac}}$ \\
& 8 & $15.4^{\mathrm{b}}$ & 29.1 & 62.5 & 40.1 & $11.2^{\mathrm{ABa}}$ \\
\hline
\end{tabular}

$\mathrm{a}, \mathrm{b}-\mathrm{P}<0.05$

significantly. No differences were found either in the content of crude fibre, NDF or ADF depending on the type of feed and time of sampling.

The amount of dry matter, crude protein and fibre, NDF, ADF and ADL in rumen digesta 4 and $8 \mathrm{~h}$ after feeding were independent of the protein source (Table 5), but before feeding (i.e. $12 \mathrm{~h}$ after the previous feeding) there was $1.8 \mathrm{~kg}$ DM more in the rumen of cows fed fish meal and $0.4 \mathrm{~kg}$ more crude protein. At this time, the total amount of crude fibre, NDF and ADF was higher in these cows than in those fed the rapeseed oilmeal ration.

TABLE 5

The amount DM, protein, fibre, NDF, ADF and ADL in the rumen contents $(\mathrm{kg})$ in different time after feeding

\begin{tabular}{ccrccccc}
\hline Diet & $\begin{array}{c}\text { Time } \\
\mathrm{h}\end{array}$ & DM & $\begin{array}{c}\text { Crude } \\
\text { protein }\end{array}$ & $\begin{array}{c}\text { Crude } \\
\text { fibre }\end{array}$ & NDF & ADF & ADL \\
\hline \multirow{4}{*}{$\mathrm{R}$} & 0 & $7.09 \pm 0.88$ & $1.01 \pm 0.13$ & $1.99 \pm 0.26$ & $4.42 \pm 0.55$ & $2.69 \pm 0.36$ & $0.95 \pm 0.15$ \\
& 4 & $10.31 \pm 1.52$ & $1.47 \pm 0.27$ & $3.11 \pm 0.85$ & $6.28 \pm 1.51$ & $4.04 \pm 0.85$ & $1.17 \pm 0.24$ \\
& 8 & $9.13 \pm 0.72$ & $1.30 \pm 0.03$ & $2.66 \pm 0.38$ & $5.62 \pm 0.36$ & $3.65 \pm 0.32$ & $1.11 \pm 0.08$ \\
& 0 & $8.89 \pm 1.25$ & $1.43 \pm 0.18$ & $2.58 \pm 0.41$ & $5.56 \pm 0.89$ & $3.69 \pm 0.62$ & $0.87 \pm 0.11$ \\
F & 4 & $10.33 \pm 0.63$ & $1.59 \pm 0.05$ & $2.80 \pm 0.12$ & $6.19 \pm 0.25$ & $3.53 \pm 0.20$ & $0.89 \pm 0.03$ \\
& 8 & $9.05 \pm 0.81$ & $1.39 \pm 0.10$ & $2.64 \pm 0.31$ & $5.67 \pm 0.65$ & $3.64 \pm 0.48$ & $1.02 \pm 0.16$ \\
\hline
\end{tabular}

$\pm \mathrm{SD}$

The content of nutrients that could potentially undergo degradation in the rumen (computed from the difference in the composition of the digesta and residue after its incubation in the rumen for $288 \mathrm{~h}$, assuming that reaching the critical size by particles did not cause them to move to the further parts of the digestive tract) before feeding was somewhat larger when feeding the ration containing fish meal than rapeseed oilmeal (Table 6). This tendency was also observed $8 \mathrm{~h}$ after feeding, while $4 \mathrm{~h}$ after feeding the potential digestibility of 
TABLE 6

Potential digestibility (\%) of DM, protein, fibre, NDF, ADF and ADL of the rumen contents in different time after feeding

\begin{tabular}{cccccccc}
\hline Diet & $\begin{array}{c}\text { Time } \\
\mathrm{h}\end{array}$ & DM & $\begin{array}{c}\text { Crude } \\
\text { protein }\end{array}$ & $\begin{array}{c}\text { Crude } \\
\text { fibre }\end{array}$ & NDF & ADF & ADL \\
\hline \multirow{4}{*}{$\mathbf{R}$} & 0 & 55.9 & 74.7 & $43.2^{\mathrm{a}}$ & $46.4^{\mathrm{a}}$ & $37.6^{\mathrm{a}}$ & $41.0^{\mathrm{a}}$ \\
& 4 & 66.5 & 84.5 & $57.4^{\mathrm{b}}$ & $57.6^{\mathrm{b}}$ & $55.1^{\mathrm{b}}$ & $45.8^{\mathrm{a}}$ \\
& 8 & 59.7 & 80.2 & $47.6^{\mathrm{a}}$ & $50.7^{\mathrm{b}}$ & $45.6^{\mathrm{abc}}$ & $42.7^{\mathrm{a}}$ \\
& 0 & 63.5 & 82.4 & $53.9^{\mathrm{b}}$ & $55.9^{\mathrm{b}}$ & $55.2^{\mathrm{b}}$ & $39.3^{\mathrm{a}}$ \\
$\mathrm{F}$ & 4 & 64.9 & 82.2 & $55.6^{\mathrm{b}}$ & $57.6^{\mathrm{b}}$ & $47.6^{\mathrm{c}}$ & $29.1^{\mathrm{b}}$ \\
& 8 & 63.4 & 81.3 & $55.6^{\mathrm{b}}$ & $57.4^{\mathrm{b}}$ & $53.6^{\mathrm{b}}$ & $45.9^{\mathrm{a}}$ \\
\hline
\end{tabular}

$\mathrm{a}, \mathrm{b}-\mathrm{P}<0.05$

DM, crude protein, crude fibre, NDF, ADF and ADL in the rumen contents of cows receiving ration $F$ was lower than in cows fed ration $R$. A significant effect of the protein source $(P<0.05)$ was found on the potential digestibility of crude fibre, NDF, ADF and ADL, but no such effect was seen on the digestibility of dry matter and crude protein in the rumen contents.

TABLE 7

The amount $(\mathrm{kg})$ of digested DM, protein, fibre, NDF, ADF and ADL in the rumen contents

\begin{tabular}{|c|c|c|c|c|c|c|c|}
\hline Diet & $\underset{h}{\text { Time }}$ & $\mathrm{DM}$ & $\begin{array}{l}\text { Crude } \\
\text { protein }\end{array}$ & $\begin{array}{l}\text { Crude } \\
\text { fibre }\end{array}$ & NDF & ADF & ADL \\
\hline $\mathbf{R}$ & $\begin{array}{l}0 \\
4 \\
8\end{array}$ & $\begin{array}{l}3.98 \pm 0.76 \\
6.82 \pm 0.60 \\
5.48 \pm 1.02\end{array}$ & & $\begin{array}{l}0.86 \pm 0.19 \\
1.78 \pm 0.44 \\
1.29 \pm 0.43\end{array}$ & & & $\begin{array}{l}0.39 \pm 0.12 \\
0.53 \pm 0.07 \\
0.47 \pm 0.04\end{array}$ \\
\hline$F$ & $\begin{array}{l}0 \\
4 \\
8\end{array}$ & $\begin{array}{l}5.64 \pm 0.69 \\
6.70 \pm 0.26 \\
5.73 \pm 0.43\end{array}$ & $\begin{array}{l}1.17 \pm 0.11 \\
1.31 \pm 0.03 \\
1.13 \pm 0.06\end{array}$ & $\begin{array}{l}1.39 \pm 0.19 \\
1.56 \pm 0.03 \\
1.46 \pm 0.14\end{array}$ & $\begin{array}{l}3.10 \pm 0.43 \\
3.56 \pm 0.06 \\
3.24 \pm 0.31\end{array}$ & $\begin{array}{l}2.03 \pm 0.26 \\
1.68 \pm 0.09 \\
1.94 \pm 0.23\end{array}$ & $\begin{array}{l}0.34 \pm 0.07 \\
0.26 \pm 0.05 \\
0.47 \pm 0.10\end{array}$ \\
\hline
\end{tabular}

$\pm \mathrm{SD}$

The protein source also had no effect on the amount of potentially digestible dry matter and nutrients in the rumen (Table 7). The amount of digestible dry matter, crude protein and crude fibre, NDF, ADF and ADL available in the rumen 4 and $8 \mathrm{~h}$ after feeding was similar when both rations were fed. Before feeding, there was more DM and its associated nutrients in the rumen of cows fed ration $F$ than in the rumen of cows fed ration $R$.

The largest part of DM (40-50\%) in the rumen digesta was composed of the smallest fraction of particles (D below $0.25 \mathrm{~mm}$ ), which in our study was not retained on the sieves, but flowed out of the separator along with the water (Table 8). Particles under $1 \mathrm{~mm}$ (fractions $\mathrm{C}$ and D) made up about $2 / 3$ of the $\mathrm{DM}$ of rumen content. When feeding both rations, 4 and $8 \mathrm{~h}$ after feeding, at least 
Percentage of different particle fractions DM of total DM of the rumen contents

TABLE 8

\begin{tabular}{cccccc}
\hline Diet & $\begin{array}{c}\text { Time } \\
\mathrm{h}\end{array}$ & $\begin{array}{c}\mathrm{A} \\
>5 \mathrm{~mm}\end{array}$ & $\begin{array}{c}\mathrm{B} \\
1-5 \mathrm{~mm}\end{array}$ & $\begin{array}{c}\mathrm{C} \\
0.25-1.0 \mathrm{~mm}\end{array}$ & $\begin{array}{c}\mathrm{D} \\
<0.25 \mathrm{~mm}\end{array}$ \\
\hline $\mathrm{R}$ & 0 & 8.4 & $22.8^{\mathrm{a}}$ & 27.2 & $41.6^{\mathrm{A}}$ \\
$\mathrm{F}$ & 0 & 8.1 & $19.1^{\mathrm{b}}$ & 22.5 & $50.3^{\mathrm{B}}$ \\
$\mathrm{R}$ & 4 & 12.7 & 23.3 & 22.4 & $41.6^{\mathrm{A}}$ \\
$\mathrm{F}$ & 4 & 13.5 & 22.3 & 19.9 & $44.3^{\mathrm{B}}$ \\
$\mathrm{R}$ & 8 & 13.6 & 22.5 & 24.4 & $39.5^{\mathrm{A}}$ \\
$\mathrm{F}$ & 8 & 11.7 & 21.2 & 19.9 & $47.2^{\mathrm{B}}$ \\
\hline
\end{tabular}

$\mathrm{a}, \mathrm{b}-\mathrm{P}<0.05$

TABLE 9

Chemical composition of the particle fractions of rumen contents, $\%$

\begin{tabular}{|c|c|c|c|c|c|c|c|}
\hline Diet & $\underset{\mathrm{h}}{\mathrm{Time}}$ & $\begin{array}{c}\text { Particle } \\
\text { size }\end{array}$ & $\begin{array}{l}\text { Crude } \\
\text { protein }\end{array}$ & $\begin{array}{l}\text { Crude } \\
\text { fibre }\end{array}$ & NDF & ADF & $\mathrm{ADL}$ \\
\hline \multirow{4}{*}{$\mathrm{R}$} & \multirow{4}{*}{0} & A & $7.9^{b}$ & $40.7^{a}$ & 82.4 & 51.6 & $9.3^{\mathrm{A}}$ \\
\hline & & B & $7.2^{\mathrm{a}}$ & $40.5^{\mathrm{a}}$ & 84.0 & 53.5 & $11.1^{\mathrm{B}}$ \\
\hline & & C & $8.4^{b}$ & $41.2^{\mathrm{a}}$ & 82.7 & 53.0 & $13.9^{\mathrm{C}}$ \\
\hline & & mean & 7.8 & 40.8 & 83.0 & 52.7 & 11.4 \\
\hline & A & $9.2^{c}$ & $40.4^{a}$ & 82.5 & 48.7 & $8.3^{\mathrm{A}}$ \\
\hline $\mathrm{F}$ & 0 & B & $7.8^{b}$ & $43.9^{b}$ & 85.9 & 51.9 & $10.5^{\mathrm{B}}$ \\
\hline \multirow{3}{*}{\multicolumn{2}{|c|}{$\begin{array}{l}810+820 \\
50.0+320 \\
30.09450 .09\end{array}$}} & $\mathrm{C}$ & $7.9^{b}$ & $42.8^{b}$ & 86.3 & 55.2 & $11.5^{\mathrm{B}}$ \\
\hline & & mean & 8.3 & 42.4 & 84.9 & 51.9 & 10.1 \\
\hline & & A & $8.4^{\mathrm{b}}$ & $40.9^{\mathrm{a}}$ & 82.0 & 50.2 & $9.1^{\mathrm{A}}$ \\
\hline \multirow[t]{4}{*}{$\mathrm{R}$} & 4 & B & $7.5^{\mathrm{a}}$ & $43.2^{\mathrm{b}}$ & 83.8 & 52.5 & $11.0^{\mathrm{B}}$ \\
\hline & & C & $9.2^{c}$ & $40.1^{a}$ & 82.0 & 52.9 & $14.9^{\mathrm{C}}$ \\
\hline & 68 & mean & 8.4 & 41.4 & 82.6 & 51.9 & 11.7 \\
\hline & & A & $9.8^{c}$ & $40.8^{\mathrm{a}}$ & 82.3 & 50.2 & $8.9^{\mathrm{A}}$ \\
\hline \multirow[t]{4}{*}{ F } & 4 & B & $8.7^{\mathrm{b}}$ & $42.0^{\mathrm{b}}$ & 85.1 & 53.8 & $9.5^{\mathrm{A}}$ \\
\hline & & $\mathrm{C}$ & $9.4^{c}$ & $40.2^{\mathrm{a}}$ & 82.9 & 51.2 & $10.5^{\mathrm{B}}$ \\
\hline & & mean & 9.3 & 41.0 & 83.4 & 51.7 & 9.6 \\
\hline & & A & $8.4^{b}$ & $40.5^{\mathrm{a}}$ & 82.5 & 51.5 & $10.4^{\mathrm{A}}$ \\
\hline \multirow[t]{4}{*}{$\mathrm{R}$} & 8 & B & $7.1^{\mathrm{a}}$ & $43.9^{b}$ & 84.9 & 54.8 & $11.2^{\mathrm{A}}$ \\
\hline & & $\mathrm{C}$ & $8.2^{\mathrm{b}}$ & $40.5^{\mathrm{a}}$ & 82.1 & 54.5 & $14.9^{\mathrm{B}}$ \\
\hline & & mean & 7.9 & 41.6 & 83.2 & 53.6 & 12.2 \\
\hline & & A & $8.7^{\mathrm{b}}$ & $40.4^{\mathrm{a}}$ & 82.6 & 48.1 & $6.9^{A}$ \\
\hline \multirow[t]{3}{*}{ F } & 8 & B & $8.3^{b}$ & $41.6^{\mathrm{ab}}$ & 84.2 & 50.7 & $10.5^{\mathrm{B}}$ \\
\hline & & $\mathrm{C}$ & $9.3^{\mathrm{c}}$ & $40.4^{a}$ & 82.4 & 50.9 & $10.8^{\mathrm{B}}$ \\
\hline & & mean & 8.8 & 40.8 & 83.1 & 49.9 & 9.4 \\
\hline
\end{tabular}

$\mathrm{a}, \mathrm{b}-\mathrm{P}<0.05 ; \mathrm{A}, \mathrm{B}-\mathrm{P}<0.01$ 
TABLE 10

Outflow rates $(\% / \mathrm{h})$ of rumen particulate and liquid fraction and critical particle size, $\mathrm{mm}$

\begin{tabular}{lcc}
\hline Indices & $\mathrm{R}$ & $\mathrm{F}$ \\
\hline Solid outflow rate & 6.5 & 6.7 \\
Liquid outflow rate & 14.9 & 16.1 \\
Critical particle size & 0.52 & 0.53 \\
\hline
\end{tabular}

$64 \%$ of the rumen DM was in a state allowing particles to flow out of the rumen, while $12 \mathrm{~h}$ (time 0 - before feeding) after feeding their amount rose $(\mathrm{P}<0.01)$ to 69 and $73 \%$, respectively when feeding rations $R$ and $F$.

The type of ration had a significant effect $(\mathrm{P}<0.05)$ on the share of particles in fraction $\mathrm{B}$ ( 1 to $5 \mathrm{~mm})$ in the DM of the rumen content. More particles were found when the rapeseed meal was given. Also, the share of fraction D particles (under $0.25 \mathrm{~mm}$ ) was higher in the rumen contents of cows fed the fish meal ration $(\mathrm{P}<0.01)$.

The rumen content of cows fed ration $F$ contained more protein in all of the fractions (Table 9) than in the cows receiving ration $R$. Fraction $B$ particles contained $(\mathrm{P}<0.05)$ less protein and more crude fibre than the other fractions, both when the rapeseed meal and fish meal rations were given. No effect of the ration on crude fibre or NDF and ADF in any of the fractions was found, but it did affect $(\mathrm{P}<0.01)$ the amount of ADL. The average share of ADL in particles larger than $0.25 \mathrm{~mm}$ (fractions $\mathrm{A}, \mathrm{B}$ and $\mathrm{C}$ ) was about $12 \%$ when ration $\mathrm{R}$ was fed, and under $10 \%$ when the fish meal-containing ration was given. The ADL content differed $(\mathrm{P}<0.01)$ between fractions, and rose as particle size decreased. No significant differences were found in chemical composition of the fractions depending on the time of sampling. Particles B and C sampled before feeding from the rumen of cows fed ration $F$ contained less protein than when sampled 4 and $8 \mathrm{~h}$ after feeding, but when the ration $\mathrm{R}$ was given, no such tendency was noted.

The outflow rate of the solid and liquid fractions from the rumen and the critical size of particles did not depend on the type of ration provided (Table 10).

\section{DISCUSSION}

Rapeseed oilmeal or fish meal protein, which differ in their degradation rate in the rumen, constituted about $30 \%$ of crude protein in the rations. The effective degradability of rapeseed oilmeal protein is 68\% (Dakowski et al.,1996) that of fish meal, 37\% (Dakowski, 1992).

The rumen contents contained on average 76.8 to $87 \%$ of the solid fraction, and its share did not depend on the time from feeding or dietary protein source. 
The rumen contents are characterized by a solid part that contains large particles of feed that is situated in the upper part of the rumen, and by the liquid fraction that is in the lower part and contains small particles and bacterial fermentation products (Van Soest, 1994). In this experiment, the division of rumen contents into its solid and liquid parts was imprecise, since by manual emptying of the rumen, the liquid separated away from the solid part during the removal of the contents from the rumen. The estimated proportion between the solid and liquid part could therefore be burdened with considerable error.

The studies of Gasa et al. (1991) showed that the type of silage fed has an effect on the amount of rumen content in cows, and that the amount of dry matter in the content depended on the amount of concentrate in the ration. In our experiment, both the average amount of digesta and its dry matter content were similar, which can indicate that the protein source does not affect these parameters. The slight differences in the amount of dry matter as well as protein and fibre in the rumen contents when rations $F$ and $R$ were fed resulted from the higher content of these components at time 0 , i.e. $12 \mathrm{~h}$ after feeding ration $\mathrm{F}$. May be that the slower degradation of fish meal protein than rapeseed oilmeal affected the amount of DM in the rumen content at time 0 , but already after $4 \mathrm{~h}$ from giving a new portion of feed the amount of DM and its components were similar, regardless of the protein source in the diet. This may suggest that the rate of outflow of solid particles from the rumen during the day is not uniform and, in the case of ration $\mathrm{F}$ equaled at least $750 \mathrm{~g} \mathrm{DM} / \mathrm{h}$, which is $8.4 \% / \mathrm{h}$, while when feeding ration $\mathrm{R}$ this figure equaled only $310 \mathrm{~g} / \mathrm{h}$, i.e. $4.4 \% / \mathrm{h}$ of DM taken up, assuming that the portion of feed containing $4.46 \mathrm{~kg}$ DM was consumed immediately after being given. In reality, the intake of this portion took about 30 $\mathrm{min}$. It was shown that the rate of outflow from sheep rumen of particles less than $1.19 \mathrm{~mm}$ was higher $(3.59 \% / \mathrm{h})$ than that of larger particles, $1.68-2.38 \mathrm{~mm}$ $(2.52 \% / \mathrm{h}$; Moon et al., 1986). In the rumen content of cows fed diet $\mathrm{F}$ at time 0 about $73 \%$ of DM was made up of particles under $1 \mathrm{~mm}$, while when feeding diet R, they made up under $69 \% \mathrm{DM}$. After $4 \mathrm{~h}$ of given feed, in both cases the amount of particles under $1 \mathrm{~mm}$ was equal (64\% of DM content), which may confirm the hypothesis about their greater outflow rate at time $0-4 \mathrm{~h}$ when ration F was fed.

The more intensive contractions of the reticulum during eating (Balch, 1971) and the rapid fermentation of barley starch, of which there was more in ration $F$ than $R$, could have been the causes of the faster loss of dry matter from the contents of the rumen during the first $4 \mathrm{~h}$ after feeding.

The content of the potentially digestible dry matter and protein in the rumen of both rations did not differ significantly, while fibre in ration $F$ was potentially better digested $(\mathrm{P}<0.05)$ in the rumen, which can be explained by the higher activity of carboxymethycellulase and xylanase attached to the in the digesta 
particles when this ration was fed as compared with ration $\mathbf{R}$ (Michałowski et al., 1997). This supports the suggestion of McAllan and Smith (1984) on the beneficial effect of fish meal protein on digesting fibre, while being in disagreement with the results of Zerbini et al. (1988). It also seems that the poorer digestibility of ration $\mathrm{R}$ fibre may have been the result of the lower digestibility of rapeseed meal fibre, which accounted for almost $6 \%$ of the fibre in this ration.

The potential digestibility of DM in the rumen contents $4 \mathrm{~h}$ after feeding ration $\mathrm{F}$ was lower than when ration $\mathrm{R}$ was fed. It seems that this was caused not only by the slower fish meal protein degradation, which could have lowered the level of ammonia in the rumen and synthesis of bacterial protein (Hespell and Bryant, 1979), but also by the suggested above faster rate of outflow of particles $0-4 \mathrm{~h}$ after feeding ration $\mathrm{F}$ than when ration $\mathrm{R}$ was given.

Changes during the day in the share of variously sized particles in the dry matter of the rumen contents were small. After feeding, the proportion of the largest particles rose slightly while the share of particles smaller than $5 \mathrm{~mm}$ did not depend on the time when the sample was taken from the rumen. Gasa et al. (1991) and Huhtanen et al. (1992) obtained similar results, although in their experiments the reduction in the largest particles with time after feeding was greater, which can be explained by the easier and faster breakdown of silage particles than of the hay used in our experiment. Differences were found, however, in the proportion of dry matter in the fraction under $0.25 \mathrm{~mm}$ in the dry matter of the rumen contents between rations $F$ and $R$, what could explained with faster passage into the liquid fraction of fish meal components and starch, which had a larger share in ration $\mathbf{F}$ than in ration $\mathbf{R}$.

When the size of the particles in the rumen content and in faeces is determined by wet-sieving, the method of separation, i.e. time, amplitude, interval, as well as water pressure and flow rate through the separator, can have a considerable effect. These methodological details are not always reported in papers, which makes interpretation of results difficult. Mertens et al. (1984) pointed out this difficulty when writing about the need to characterize and evaluate the techniques used to separate particles of various size. The time of sampling did not affect the chemical composition of digesta particles, but in all of the fractions of rumen content in cows fed ration $\mathrm{F}$ a slightly higher protein content was found than when ration $\mathrm{R}$ was given, which is difficult to interpret. As the particle size decreased, their lignin content increased, which was also found by Jung et al. (1990) and Huhtanen et al. (1992). According to the latter authors, as the particle size decreases, the activity of cellulolytic and accompanying enzymes increases, which augments the decline in the content of susceptible components, thus increasing the proportion of the remaining difficult to digest lignin. The outflow rate from the rumen of the solid and liquid contents did not depend on the protein source in the ration and was close to the values given by other authors 
(Eliman and Ørskov, 1981; Owens and Goetsch, 1986; Ørskov et. al., 1988; Huhtanen and Kukkonen, 1995).

The critical size of particles found in this experiment on the basis of particle separation in faeces was much smaller than that given by Poppi et al. (1980) and Lechner-Doll and Engelhardt (1989), which is difficult to explain, and could have been caused by using a different technique to separate particles.

Summarizing, it can be stated that protein with varying rates of degradation did not affect the amount of rumen content, or the outflow rate of the solid and liquid digesta fractions, or the critical size of particles.

After feeding a ration containing fish meal, the rumen content contained more protein in all of the digesta fractions and more small particles that could leave the rumen than when the rapeseed oilmeal ration was fed. Regardless of the type of protein in the diet, 4 and $8 \mathrm{~h}$ after feeding at least $64 \%$, while after $12 \mathrm{~h}$, about $70 \%$ of the feed dry matter was in a state permitting it to flow out of the rumen.

\section{REFERENCES}

Balch C.C., 1971. Proposal to use time spent chewing as an index of the extent to which ruminants possess the physical property of fibrousness characteristics of roughages. Brit. J. Nutr. 26, 383.476

Bowman J.G.P., Firkins J.L., 1996. In situ particle size reduction as affected by forage species and grinding mesh size. J. Anim. Sci. 74, 439-446

Dakowski P., 1992. Dietary protein source in the diet and digestibility of fibre fractions in sheep. J. Anim. Feed Sci. 1, 237-253

Dakowski P., Weisbjerg M.R., Hvelplund T., 1996. The effect of temperature during processing of rapeseed meal on amino acid degradation in the rumen and digestion in the intestine. Anim. Feed Sci. Technol. 58, 213-226

Elimam M. E., Ørskov E. R., 1981. Determination of rate of outflow of protein supplements from the rumen by measuring the rate of excretion of chromium-treated protcin supplements and polyethylene glycol in the faeces. Anim. Prod. 32, 386, Abstr.

Gasa J., Holtenius K., Sutton J.D., Dhanoa M.S., Napper D.J., 1991. Rumen fill and digesta kinetics in lactating Friesian cows given two levels of concentrates with two types of grass silage ad lib. Brit. J. Nutr. 66, 381-398

Hespell R.B., Bryant M.P., 1979. Efficiency of rumen microbial growth: influence of some theoretical and experimental factors on YATP. J. Anim. Sci. 49, 1640-1659

Huhtanen P., Kukkonen U., 1995. Comparison of methods, markers, sampling sites and models for estimating digesta passage kinetics in cattle fed at two levels of intake. Anim. Feed Sci. Technol. $52,141-158$

Huhtanen P., Dakowski P., Vanhatalo A., 1992. Composition,digestibility and particle-associated enzyme activities in rumen digesta as influenced by particle size and time after feeding. $\mathbf{J}$. Anim. Feed Sci. 1, 223-235 
Jung H.J.G., Åman P., Graham H., 1990. Profile of fibre composition in lucerne (Medicago sativa) hay and rumen digesta as influenced by particle size and time after feeding. J. Sci. Food Agric. $51,411-416$

Lechner-Doll M., Engelhardt von W., 1989. Particle size and passage from the forestomach in camels compared to cattle and sheep fed a similar diet. J. Anim. Physiol. Anim. Nutr. 61,120-128

McAllan A.B., Griffith E.S., 1987. The effects of different sources of nitrogen supplementation on the digestion of fibre components in the rumen of steers. Anim. Feed Sci. Technol. 17, 65-73

McAllan A.B., Smith R.H., 1983. Estimation of flows of organic matter and nitrogen components in postruminal digesta and effects of level of dietary intake and physical form of protein supplement on such estimates. Brit. J. Nutr. 49, 119-127

McAllan A.B., Smith R.H., 1984. The efficiency of microbial protein in the rumen and the degradability of feed nitrogen between the mouth and abomasum in steers given different diets. Brit. J. Nutr. 51, 77-83

Mertens D.R., Strawn T.L., Cardoza R.S., 1984. Modelling ruminal particle size reduction: its relationship to particle size description. Techniques in particle size analysis of feed and digesta in ruminants. Proceeding of Workshop held at the Banff Centre. P.M. Kennedy (Editor). Can. Soc. of Anim. Sci., Occasional Publication 1. Edmonton, pp. 134-141

Michałowski T., K wiatkowska E., Pająk J.J., 1997. The effect of diet on microbial mass, xylanase and CMC-ase activities in whole rumen digesta and in different fractions of the rumen contents of cows. J. Anim. Feed Sci. 6, 485-497

Moon T.H., Yuk J.Y., Ha J.K, Han I.K., 1986. Effects of particle size of corn on the outflow rate, protein and dry matter degradation, and digestibility in sheep. Korean J. Anim. Sci. 28, 720-726

Ørskov E.R., Ojwang l., Reid G.W., 1988. A study on consistency of differences between cows in rumen outflow rate of fibrous particles and other substrates and consequences for digestibility and intake of roughages. Anim. Prod. 47, 45-51

Owens F.N., Goetsch A.L., 1986. Digesta passage and microbial protein synthesis. Control of digestion and metabolism in ruminants. In: L.P. Milligan, W.L. Grovum, A. Dobson (Editors). Proceeding of the 6th International Symposium on Ruminant Physiology, Banff (Canada). Prentice-Hall, Englewood Cliffs, NJ (USA), pp. 196-226

Poppi D.P., Hendricksen R.E., Minson D.J., 1985. The relative resistance to escape of leaf and stem particles from the rumen of cattle and sheep. J. Agric. Sci., Camb. 105, 9-14

Poppi D.P., Norton B.W., Minson D.J., Hendricksen R.E., 1980. The valitidity of the critical size theory for particles leaving the rumen. J. Agric. Sci., Camb. 94, 275-280

Udén P., Colucci P.E., Van Soest P.J., 1980. Investigation of chromium, cerium and cobalt as markers in digesta. Rate of passage studies. J. Sci. Food Agric. 31, 625-632

Ulyatt M.J., Dellow D.W., John A., Reid C.S.W., Waghorn G.C., 1986. Contribution of chewing during eating and rumination to the clearance of digesta from the ruminoreticulum. Control of digestion and metabolism in ruminants. In: L.P. Milligan, W.L. Grovum, A. Dobson (Editors). Proceeding of the 6th International Symposium on Ruminant Physiology, Banff (Canada). Prentice-Hall, Englewood Cliffs, NJ (USA), pp. 498-515

Van Soest P.J., 1973. Collaborative study of acid detergent fibre and lignin. J. Assoc. Off. Anal. Chem. 56, 781-784

Van Soest P.J., 1994. Nutritional Ecology of the Ruminant. 2nd Edition, Cornell University Press, Ithaca, NY

Zerbini E., Polan C.E., Herbein J.H., 1988. Effect of dietary soybean meal and fish meal on protein digesta flow in Holstein cows during early and midlactation. J. Dairy Sci. 71, I248-1258 


\section{STRESZCZENIE}

Wielkość, skład i tempo wypływu cząstek ze żwacza krów żywionych dawkami z różnym źródłem bialka

Trzy nielaktujące krowy o masie ciała ok. $470 \mathrm{~kg}$ żywiono dwa razy dziennie dawkami składającymi się z siana łąkowego i mieszanki treściwej ( $79: 21)$ zawierającej mączkę rybną (F) lub pockstrakcyjną śrutę rzepakową (R). Białko mączki rybnej i śruty rzepakowej stanowilo $30 \%$ bialka dawki.

Treść żwacza ewakuowano ręcznie przed karmieniem (czas 0) oraz 4 i 8 godz. po podaniu paszy. Przerwa między kolejnymi ewakuacjami treścj wynosiła co najmniej 7 dni. Szybkość wypływu ze żwacza frakcji stalej oznaczono przy użyciu mordantu $\mathrm{Cr}$ (siana), a frakcji płynnej stosując Co-EDTA. Rozdział cząstek treści wykonano przy pomocy przesiewania na mokro na sitach o wielkości oczek 5,$0 ; 1,0$ i $0,25 \mathrm{~mm}$.

llość treści żwacza oraz zawartej w niej suchej masy i białka w różnym czasie po karmieniu nie zależała od rodzaju białka w dawce. Potencjalna strawność włókna surowego, ADF, NDF i ADL treści żwacza była większa $(P<0,05)$ przy skarmianiu dawki zawierającej mączkę rybną, zwlaszcza w 8 i 12 godz. po podaniu paszy. Udział cząstek różnej wielkości w suchej masie calej treści nie zmieniał się z uplywem czasu po karmieniu. Udział cząstek mniejszych niż $1 \mathrm{~mm}$ przy żywieniu dawką F był tylko nieco większy niż przy skarmianiu dawki R. Przy podawaniuaniu dawki F stwierdzono istotnie większą zawartość białka w cząstkach powyżej $5 \mathrm{~mm}$ i ligniny w cząstkach poniżej $1 \mathrm{~mm}$. Przy skarmianiu obydwóch dawek w czasie 4 i 8 godz. po karmieniu $64 \%$ suchej masy treści stanowiły cząstki mogące opuścić żwacz, mniejsze niż $1 \mathrm{~mm}$, a po $12 \mathrm{godz}$. ich ilość wzrastała do ok. $70 \%$.

Wielkość krytyczna cząstek $(0,52 \mathrm{~mm})$ oraz szybkość wypływu frakcji stalej $(6,6 \% /$ godz. $)$ i frakcji płynnej $(15,5 \% /$ godz.) treści żwacza nie zależały od rodzaju białka w dawce. 